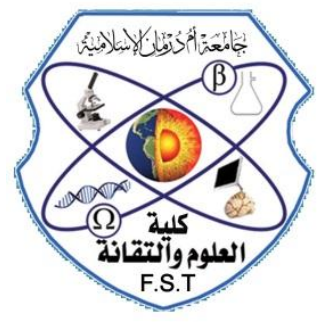

\title{
JOURNAL OF THE FACULTY OF SCIENCE AND TECHNOLOGY
}

\author{
(JFST) Issue No (5) - (ISSN 1858-6007)
}

مجلة كلية العلوم والتقانة - جامعة أم درمان الاسلامية - وزارة التعليم العالى والبحث العلمى ، السودان

Research Article

\section{The Efficiency of Two Nile Fishes as Biocontrol Agents Against Different Stages of Schistosomiasis Intermediate Host.}

\author{
A. A. Afifi ${ }^{1}$; A. A. Ahmed ${ }^{2}$ \\ ${ }^{1}$ Zoology Department, Faculty of Science and Technology, Omdurman Islamic University, Khartoum, \\ Sudan.azzamafifi@yahoo.com. \\ ${ }^{2}$ Zoology Department, Faculty of Sciences, Khartoum University, Khartoum, Sudan. \\ abdellazziz@hotmail.com
}

\begin{abstract}
The present investigation is dealing with the biological control of schistosome intermediate host, two Nile fishes Debs (Labeo niloticus) and the Nile Bulti or Tilabia (Cyrinus carbio) were selected to determine their efficiency to control schistosomiasis intermediate host (snails). Six laboratory sets of experiments were designed, three for Bulinus truncatus and other three for Biomphalaria pfeifferi. The first set in each snail species were control group, while the other two provided with the two Nile fishes, to investigate the efficiency of the selected biocontrol agents. In control set, gradual reduction of egg-masses, neonates and adult snails of both schistosomiasis snails. Compared with the control set, the two fishes verified to be highly efficient predators against egg-masses and neonates of the two snails $(\mathrm{P}<0.001)$. While in case of the adults of both species reduced also very gradually.
\end{abstract}

Key words: Labeo niloticus: Tilabia (Cyrinus carbio: schistosomiasis

\section{Background}

Schistosomiasis is both preventable and curable, but unfortunately, it remains a serious public health problem in the endemic countries. Poverty and scarce financial resources go hand in hand with this chronic disease. Poverty, and inadequate sanitation and water supply are also conditions associated with the disease (WHO, 1998). The agricultural sector plays a pivot role in the Sudanese economy. But unfortunately, in the aforesaid schemes a dramatic increase in both, prevalence and intensity of Schistosomiasis was reported (Omer et. al., 1976; Kardaman et al., 1982; Hilali, 1992; Ahmed, 1998 and Ahmed, 2006).

The current study is dealing with the biological control, which depends on the natural enemies of schistosome intermediate host. In the Sudan, Biomphalaria pfeifferi and Bulinus truncatus are the intermediate hosts of Schistosoma mansoni and Schistosoma haematobium respectively. Furthermore, the two snail species distributed in all States of 
the Sudan (Babiker, 1987; Hilali, 1992 and Ahmed, 1998 \& 2003). Thus, the two snail species were chosen to be the target species of a designed set of laboratory experiments and systematic monitory of their abundance and dynamics in natural waterbodies.

The overall objective of the present investigation is to determine the efficiency of two macrofaunal forms as biocontrol agents of all stages (egg-masses, neonates and adults) of schistosomiasis intermediate-hosts, in the laboratory.

\section{Materials and Methods}

The selected macrofaunal forms includes two freshwater fishes: Debs (Labeo niloticus) and the Nile Bulti or Tilabia (Cyrinus carbio).

Six sets of experiments were designed, three for Bul. truncatus and the others for Biom. pfeifferi, to investigate the efficiency of the selected biocontrol agents. The experiments were designed to test the predation of the proposed biocontrol agents against eggmasses, neonates and adults of the two intermediate hosts. In each laboratory design, the natural relative proportions of the macrofaunal aquatic fishes were considered depending on the repeated sample collection from the canalization system.

\section{The First Design of Laboratory Sets}

The designed sets composed mainly of thirty plastic aquaria (3 for each snail species), with 4 liters' capacity per aquaria. Utilizing a dissecting microscope, the number of eggs was counted in each egg-mass of both Biom. pfeifferi and Bul. truncatus. It had been concluded that there are $100 \pm 2$ eggs in any randomly selected 8 egg-masses of Biom. pfeifferi and $100 \pm 2$ eggs in any 9 eggmasses of Bul. truncatus.

Each of the three plastic aquaria was provided with eight egg-masses of Biom. pfeifferi, while the other three plastic aquaria were provided with nine egg-masses of Bul. truncatus; always egg-masses were attached to polythene sheets. The first aquarium (for each species) was containing the control group, the egg-masses without any biocontrol agent. The other two aquaria were provided with the biocontrol agents.

The number of the biocontrol agents in each aquarium was manipulated weekly by replacing the dead ones by vivid forms. All aquaria were maintained in laboratory conditions. In each aquarium, the number of eggs, the surviving neonates and adults of the two snail species were counted weekly, for a period of 8 weeks. The normal kitchen sieves, with the narrow mesh size, were used to avoid washing out of the macrofaunal forms during changing the aquarium water. The loss of water in aquaria, due to evaporation, was replaced daily. Each experiment was replicated three times and averages were calculated.

\section{The Second Design of Laboratory Sets}

In these experiments, the adopted design resembled the aforementioned one, but here the target organisms are the neonates (1-2 days) of the two intermediate host snails. Each of the first three aquaria was provided with 50 Biom. pfeifferi neonates, while each of the other three aquaria was supplied with 50 Bul. truncatus neonates.

\section{The Third Design of Laboratory Sets}

Again this design symphonized the aforesaid ones, but in each aquarium only 33 adult snails from each species were utilized.

The data analysis was performed using a STATISTIX Statistical Package. The mean values for egg masses, neonates and adults were calculated and compared using Oneway ANOVA and the comparison of means was furtherly treated by Scheffe test to assess heterogeneity or homogeneity levels. 


\section{Results and Discussion}

\subsection{Control Group}

Table (1), verify the gradual reduction of egg-masses, neonates and adult snails of both schistosomiasis snails, control group. In the two snail species, there was a synchrony in the reduction rates of both the egg-masses and the neonates, while the adults of both species have more chance to survive.

\section{Efficiency of Nile Fishes}

Bulti (Cyrinus carbio) and Debsa (Labio nilotica):

In conjunction with the above, the two fishes observed to be highly efficient biocontrol agent against egg-masses and neonates of the two snails ( $\mathrm{P}<0.001)$, Tables (2) and (3). On the other side, the adults of both species reduced also very gradually, where considerable densities survived the exposure to the end of the experiment.

The intermediate-host snails are essential link in schistosomiasis life cycle. Thus, adequate knowledge of their bionomics and the factors that influence their population dynamics are required for the proper understanding of schistosomiasis transmission. Furthermore, such knowledge is needed for planning and assessment of measures directed against intermediate hosts within the integrated control approach of the disease.

The outcome of this investigation could be evaluated with regard to major point. The most important is that environmentally safe methods to control snails. Control programs of the parasitic diseases are either manipulated to prevent infection or treat after infection.

Table 1. The weekly percentage in the survival rate of Bulinus truncatus and Biomphalaria pfeifferi, control group.

\begin{tabular}{|c|c|l|l|l|l|l|l|l|l|}
\hline & $\begin{array}{r}\text { Time/Snail } \\
\text { stage }\end{array}$ & $\begin{array}{l}1^{\text {st }} \\
\text { week }\end{array}$ & $\begin{array}{l}2^{\text {nd }} \\
\text { week }\end{array}$ & $\begin{array}{l}3^{\text {rd }} \\
\text { week }\end{array}$ & $\begin{array}{l}4^{\text {th }} \\
\text { week }\end{array}$ & $\begin{array}{l}5^{\text {th }} \\
\text { week }\end{array}$ & $\begin{array}{l}6^{\text {th }} \\
\text { week }\end{array}$ & $\begin{array}{l}7^{\text {th }} \\
\text { week }\end{array}$ & $\begin{array}{l}8^{\text {th }} \\
\text { week }\end{array}$ \\
\hline \multirow{4}{*}{$\begin{array}{c}\text { Bulinus } \\
\text { truncatus }\end{array}$} & $\begin{array}{r}\text { Egg- } \\
\text { masses }\end{array}$ & 99 & 78 & 70 & 65 & 61 & 57 & 54 & 53 \\
& Neonates & 86 & 78 & 68 & 62 & 60 & 58 & 52 & 52 \\
\cline { 2 - 11 } & Adults & 99 & 99 & 96 & 93 & 93 & 93 & 87 & 84 \\
\hline \multirow{4}{*}{$\begin{array}{c}\text { Biomphalaria } \\
\text { pfeifferi }\end{array}$} & $\begin{array}{r}\text { Egg- } \\
\text { masses }\end{array}$ & 93 & 87 & 72 & 66 & 60 & 57 & 55 & 55 \\
\cline { 2 - 11 } & Neonates & 92 & 78 & 78 & 58 & 56 & 54 & 54 & 52 \\
\cline { 2 - 10 } & Adults & 99 & 99 & 96 & 96 & 87 & 81 & 78 & 78 \\
\hline
\end{tabular}

Table 2. The weekly percentage in the survival rate of Bulinus truncatus and Biomphalaria pfeifferi exposed to Nile Bulti (Cyrinus caribo).

\begin{tabular}{|l|r|l|l|l|l|l|l|l|l|}
\hline & $\begin{array}{r}\text { Time/Snail } \\
\text { stage }\end{array}$ & $\begin{array}{l}1^{\text {st }} \\
\text { week }\end{array}$ & $\begin{array}{l}2^{\text {nd }} \\
\text { week }\end{array}$ & $\begin{array}{l}3^{\text {rd }} \\
\text { week }\end{array}$ & $\begin{array}{l}4^{\text {th }} \\
\text { week }\end{array}$ & $\begin{array}{l}5^{\text {th }} \\
\text { week }\end{array}$ & $\begin{array}{l}6^{\text {th }} \\
\text { week }\end{array}$ & $\begin{array}{l}7^{\text {th }} \\
\text { week }\end{array}$ & $\begin{array}{l}8^{\text {th }} \\
\text { week }\end{array}$ \\
\hline $\begin{array}{l}\text { Bulinus } \\
\text { truncatus }\end{array}$ & $\begin{array}{r}\text { Egg- } \\
\text { masses }\end{array}$ & 0 & 0 & 0 & 0 & 0 & 0 & 0 & 0 \\
\cline { 2 - 11 } & Neonates & 0 & 0 & 0 & 0 & 0 & 0 & 0 & 0 \\
\cline { 2 - 11 } & Adults & 78 & 75 & 57 & 48 & 42 & 42 & 42 & 42 \\
\hline \multirow{4}{*}{$\begin{array}{l}\text { Biomphalaria } \\
\text { pfeifferi }\end{array}$} & $\begin{array}{r}\text { Egg- } \\
\text { masses }\end{array}$ & 0 & 0 & 0 & 0 & 0 & 0 & 0 & 0 \\
\cline { 2 - 11 } & Neonates & 0 & 0 & 0 & 0 & 0 & 0 & 0 & 0 \\
\cline { 2 - 11 } & Adults & 96 & 93 & 84 & 81 & 78 & 78 & 78 & 75 \\
\hline
\end{tabular}


Table 3. The weekly percentage in the survival rate of Bulinus truncatus and Biomphalaria pfeifferi exposed to Nile Debsa (Labio nilotica).

\begin{tabular}{|c|c|c|c|c|c|c|c|c|c|}
\hline & $\begin{array}{r}\text { Time/Snail } \\
\text { stage }\end{array}$ & $\begin{array}{l}1^{\text {st }} \\
\text { week }\end{array}$ & $\begin{array}{l}2^{\text {nd }} \\
\text { week }\end{array}$ & $\begin{array}{l}3^{\text {rd }} \\
\text { week }\end{array}$ & $\begin{array}{l}4^{\text {th }} \\
\text { week }\end{array}$ & $\begin{array}{l}5^{\text {th }} \\
\text { week }\end{array}$ & $\begin{array}{l}6^{\text {th }} \\
\text { week }\end{array}$ & $\begin{array}{l}7^{\text {th }} \\
\text { week }\end{array}$ & $\begin{array}{l}8^{\text {th }} \\
\text { week }\end{array}$ \\
\hline \multirow[t]{3}{*}{$\begin{array}{l}\text { Bulinus } \\
\text { truncatus }\end{array}$} & $\begin{array}{r}\text { Egg- } \\
\text { masses }\end{array}$ & 17 & 0 & 0 & 0 & 0 & 0 & 0 & 0 \\
\hline & Neonates & 0 & 0 & 0 & 0 & 0 & 0 & 0 & 0 \\
\hline & Adults & 96 & 87 & 87 & 81 & 63 & 63 & 60 & 54 \\
\hline \multirow{3}{*}{$\begin{array}{l}\text { Biomphalaria } \\
\text { pfeifferi }\end{array}$} & $\begin{array}{r}\text { Egg- } \\
\text { masses }\end{array}$ & 11 & 0 & 0 & 0 & 0 & 0 & 0 & 0 \\
\hline & Neonates & 0 & 0 & 0 & 0 & 0 & 0 & 0 & 0 \\
\hline & Adults & 99 & 99 & 93 & 90 & 87 & 87 & 81 & 81 \\
\hline
\end{tabular}

Bilharzia control strategies focused towards the intermediate hosts, the weak point in the parasitic vicious life cycle (Ahmed, 1998). In this way, the cost of the routine mollusciciding programs remains high and associated problems to the molluscicidal application. Thus, the biological control might be the solution after the intervention phase. In Sudan, they inhabit the main Nile, Blue and White Niles (Abu-Gideri, 1984). Cyprinus carbio is a mouth-brooder fish species since female incubates eggs in her mouth after they are laid and fertilized by the male. In average, female produce three spawns with a total egg number about 7506000 eggs per year. The optimum temperature for reproduction is $25^{\circ}-29^{\circ} \mathrm{C}$. Egg hatches in three to five days and are guarded by the female for 8-10 days after hatching ((International Center for Aquaculture and Aquatic EnvironmentICAAE, 2000). All samples of the Nile Bulti, which were collected from the field and maintained in the laboratory, were observed to be stunty (dwarf) fishes, $3-5 \mathrm{~cm}$ long. Which classify it as a fish of non-commercial value. However, the two fished have many appreciable characters encouraging their utilization as promising biocontrol agents. These include, the fishes are disease resistant, reproduce easily even in captivity, have high reproductive rates, eat wide variety of food and tolerate wide range of ecological changes and poor water quality with low dissolved oxygen levels (Huet, 1973; ICAAE, 2000).

\section{References}

Abu-Gideiri, Y. B. (1984). Fisher of the Sudan. University of Khartoum Press. Khartoum, Sudan.

Ahmed, A. A. (1998). Epidemiology of $S$. mansoni Infection in Gunaid Sugar Cane Scheme, Gezira State, Ph.D. thesis, Department of Zoology, Faculty of Science, University of Khartoum, Sudan.

Ahmed, A. A. (2003). Schistosomiasis in sugar cane schemes, Sudan. Journal of Natural Sciences. Vol 3 (B).

Ahmed, A. A. (2006). Schistosomiasis in sugar cane schemes, Sudan. Journal of Natural Sciences. Vol 4 (B). pages: 1-11

Babiker, A. (1987). Transmission and control of $S$. mansoni in the Gezira Irrigated Area of the Sudan. Ph.D. thesis. Department of Zoology, Faculty of Science, University of Khartoum, Sudan.

Hilali, A.H. (1992). Transmission of S. mansoni in the Managil Area, Sudan. Ph.D. thesis, Department of Zoology, Faculty of Science, University of Khartoum, Sudan.

Huet, M. (1973). Textbook of fish Culture: Breeding and Cultivation of fish. Translated by H. Kohn. Fishing News (Books) Ltd. Farnham, Survey, England. 
International Center for AquaticcEnvironment (ICAAE) (2000). Introduce to Tilabia culture. Alex Bocek (Edit)Auburn University, Alabama, USA.

Kardaman, M. W.; Amin, M. A.; Fenwick, A.; Cheesmond, A. K.; \& Dixan, H. G. (1982). A field trail using Praziquantel (Bitricide) to treat Schistosoma mansoni and Schistosoma haematobium infection in Gezira, Sudan. Annals of Tropical Medicine and Parasitology. 77: 297-304.
Omer, A.H.S., Homilton, P. J. S.; Marshall, T. F. \& Droper, C. C. (1976). Infection with Schistosoma mansoni in the Gezira of the Sudan. Journal of Tropical Medicine and Hygiene, 79: 151-157.

World Health Organization (1998). Schistosomiasis control. Division of control of Tropical Diseases, WHO. Fact Sheet No. 115. (WHO Home Page, In the Internet, http://www.who.Christenson/)

$* * * * *$ 